Public Choice 75: 157-170, 1993.

(C) 1993 Kluwer Academic Publishers. Printed in the Netherlands.

\title{
Welfare as a cause of poverty: A time series analysis
}

\author{
PATRICIA K. SMITH \\ Department of Social Science, University of Michigan-Dearborn, Dearborn, MI 48128-1491
}

Accepted 25 April 1991

\section{Introduction}

Since the inception of welfare programs critics have argued that giving aid to the poor dampens their incentive to provide for themselves and their dependents. ${ }^{1}$ Charles Murray's Losing Ground (1984) presents a modern reincarnation of this "work disincentive hypothesis". He notes that both nominal welfare benefits and caseloads increased during the seventies, suggesting that higher benefits cause more people to join the welfare rolls. Others contend that welfare receipt may be a necessity rather than a matter of personal choice. Even if the nonworking poor actively sought employment many would not be able to find jobs. Furthermore, many would find only low paying jobs which would not enable them to work their way out of poverty (e.g., Abraham, 1983). In this view, unemployment, labor market segmentation, and low wages cause poverty. Which view is correct?

Studies of the effects of welfare typically specify a single model and use regression analysis to test whether the data support its implications. In contrast, this paper uses the Granger (1969) causality test in a system of welfare and employment equations. This strategy offers two advantages. First, regression presumes causality whereas the Granger approach tests whether or not causality, defined in a technical sense, exists. Second, we can use a very general empirical model to test the work disincentive hypothesis as well as the implications of two competing models.

Section 2 presents three models of the welfare caseload and their implied patterns of causality. Section 3 explains Granger's concept of and test for causality. In Section 4 the test is performed, indicating the direction of causality between real AFDC benefits, the AFDC caseload, and unemployment. We then repeat the exercise using labor force participation rates rather than unemployment rates. The paper concludes with a summary of the results and their qualifications. 


\section{Three models of the welfare caseload}

A simple model of rational choice underlies the work disincentive hypothesis: An individual compares expected utility from work to the expected utility from nonwork and welfare dependency, and then chooses the state which generates the highest expected utility. Nonwork and welfare dependency give the individual benefits (BEN) and increases leisure time (L). Work yields earnings (EARN), but lowers the amount of time available for leisure. Let the dichotomous variable WELFARE represent the individual's choice:

$$
\text { WELFARE }=\left\{\begin{array}{l}
1 \text { if } \mathrm{U}\left(\mathrm{BEN}, \mathrm{L}, \mathrm{e}_{1}\right)>\mathrm{U}\left(\mathrm{EARN}, \mathrm{L}, \mathrm{e}_{2}\right) \\
0 \text { otherwise }
\end{array}\right.
$$

where $e_{1}$ and $e_{2}$ represent unobservable values regarding work and welfare.

The higher are benefits, the higher the utility from receiving welfare and the more likely the individual is to choose nonwork and welfare dependency, ceteris paribus. Thus, increasing benefits will cause increased unemployment, decreased labor force participation, and higher caseloads (i.e., more poverty). Conversely, cutting benefits (Murray's prescription) will cause decreases in unemployment, increases in labor force participation, and decreases in caseloads.

If true, three causal patterns could be observed. First, benefits cause unemployment (the choice of nonwork), which in turn causes the welfare caseload:

$$
\text { Benefits } \rightarrow \text { Unemployment } \rightarrow \text { Caseload }
$$

Second, benefits might simultaneously cause unemployment and the welfare caseload:

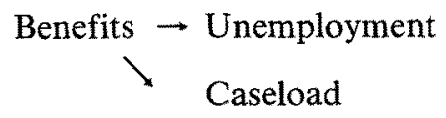

Third, benefits could directly cause the caseload through their impact on the welfare participation rates of the currently unemployed. An unemployed person may not initially be on welfare, but an increase in benefits could encourage them to participate:

\section{Benefits $\rightarrow$ Caseload}

Analyses of labor supply responses to welfare benefits often examine the separate effects of changes in the guarantee and in the tax rate. These studies generally confirm that increasing the guarantee exerts a positive income effect, lowering labor supply as long as leisure is a normal good. ${ }^{2}$ Estimates of the impact of lower tax rates suggest that labor supply would increase somewhat. However, lower tax rates would also raise the breakeven income level, increasing the number of people eligible for benefits. This mechanical response means 
that lower tax rates will increase both benefits and the caseload.

The general consensus seems to be that welfare programs cause reductions in labor supply, as the work disincentive model predicts, but that the decreases are fairly small. Danziger et al. (1981) estimate that the combined benefits for AFDC, Food Stamps, housing, and Medicaid caused only a $3.3 \%$ decline in overall labor supply in 1977. Moffitt (1983) notes that changes in real wages, the unemployment rate, and education exert greater influence on labor supply than do changes in welfare program parameters.

Welfare critics often overlook the fact that the rational choice model (1) also implies that increases in earnings will raise the utility from employment, increasing the likelihood that the individual will choose work, rather than welfare, ceteris paribus. Policies which improve labor markets and human capital programs which enhance earnings potential will thus reduce caseloads, increase labor force participation, and decrease unemployment. The model's two implications suggest different policy prescriptions: Spend less on the poor (cut benefits) and spend more on the poor (offer education and training programs). These implications should be considered jointly and suggest a reallocation of welfare spending, not necessarily a change in the level of spending.

Furthermore, the work disincentive hypothesis implicitly assumes that jobs are available and that individuals simply choose not to take them. However, individuals may be unemployed and welfare dependent because they are involuntarily unemployed, i.e., they are laid off or no jobs are available in their area. Abraham (1983) presents compelling evidence that there are significantly more workers than job vacancies in the United States. Bassi (1990) finds that the increase in women's welfare receipt between 1967 and 1979 partly results from an increase in their involuntary unemployment. ${ }^{3}$ Wilson (1987) argues that high unemployment rates for young, black men contributes to underclass poverty. Unemployment renders these men "unsuitable" as marriage partners, hence families tend to form without marriage. The resulting mother-only households face a greater risk of poverty and welfare receipt.

These "macroeconomic" hypotheses imply that unemployment causes the welfare caseload:

\section{Unemployment $\rightarrow$ Caseload}

Finally, public choice theories predict that growth in the number of poor may cause benefits to rise. ${ }^{4}$ First, increases in the number of poor could increase their strength as a voting bloc. The poor could use their voting power to elect officials who favor generous welfare programs. While possible, this seems unlikely given the well-documented low voter turnout among the poor. Furthermore, as Tullock (1983) explains, the costs of organizing the poor into an effective lobby are likely to be high. In any case, the more poor the more likely they are to be a significant political force. Or perhaps, the 
more poor, the greater the need for appeasement (social control) through welfare (Piven and Cloward, 1971).

Leffler (1978) argues that welfare bureaucracies and labor unions, rather than the poor, form effective pro-welfare interest groups. Labor unions may support generous welfare policies for the same reason that they support minimum wage legislation and restrictive immigration policies: All three reduce the competition for union jobs. Anderson (1987) presents evidence that AFDC payments are positively correlated with the relative political influence of organized labor. ${ }^{5}$ The larger the poor population, the greater the threat to union jobs and the more likely is the union to lobby in support of generous welfare benefits. Also, the more poor, the larger will be the welfare bureaucracy, whose members will be likely to lobby for its expansion.

Second, an increase in the number of poor relative to the number of nonpoor could alter the voting distribution. Researchers often identify the median voter as the voter with the median income. ${ }^{6}$ A large increase in the number of poor relative to the number of nonpoor could lower the median income. A poorer median voter might be more sympathetic to the plight of the poor or may simply feel more at risk of slipping into poverty. In either case, the new median voter could have a greater incentive to support a more generous welfare system. $^{\text {? }}$

If the public choice theories are correct we would observe that caseloads cause benefits:

\section{Caseloads $\rightarrow$ Benefits}

The work disincentive, macroeconomic, and public choice models predict very different patterns of causality. The actual presence and strength of each pattern remain an empirical issue to be resolved.

\section{Granger causality}

Granger (1969) proposes that $X_{t}$ "causes" $Y_{t}$ if information on past and present $X_{t}$ significantly improves the forecast of $Y_{t}{ }^{8}$ Formally, let a stationary, normally distributed bivariate autoregressive process of order $\mathrm{p}$ generate $\mathrm{X}_{\mathrm{t}}$ and $\mathrm{Y}_{\mathrm{t}}$ :

$$
\begin{aligned}
& X_{t}=a_{11}(L) X_{t-1}+a_{12}(L) Y_{t-1}+E_{1 t} \\
& Y_{t}=a_{21}(L) X_{t-1}+a_{22}(L) Y_{t-1}+E_{2 t}
\end{aligned}
$$

where $\mathrm{L}$ denotes the lag operator $(\mathrm{L}=0,1, \ldots \mathrm{p}-1)$. Assuming past and present $X_{t}$ and $Y_{t}$ represent all relevant information, $X_{t}$ Granger-causes $Y_{t}$ if the $\hat{a}_{21}(\mathrm{~L})$ differ significantly from zero. If both the $\hat{a}_{21}(\mathrm{~L})$ and $\hat{a}_{12}(L)$ are nonzero, there is feedback between the two variables: $X_{t}$ and $Y_{t}$ simultaneously 
cause each other. Note that this tests the ability of $X_{t}$ to predict $Y_{t}$, which, in a strict philosophical sense, differs from the notion that $X_{t}$ causes $Y_{t}$. Nevertheless, the test offers a better means of determining whether one series precedes ("causes") another than the simple visual inspection of time plots used by Murray and others.

\section{Granger causality and AFDC}

To test the three models of welfare caseloads we estimate systems of the following general form:

$$
\begin{aligned}
& \text { CASE }_{t}=a_{11}\left(\text { L CASE }_{t}+a_{12}\left(\text { L BEN }_{t}+a_{13}\left(L^{2}\right) \text { UNEM }_{t}+E_{1 t}\right.\right. \\
& \text { BEN }_{t}=a_{21}\left(L_{)} \text {CASE }_{t}+a_{22}(L) \text { BEN }_{t}+a_{23}(L) \text { UNEM }_{t}+E_{2 t}\right. \\
& \text { UNEM }_{t}=a_{31}\left(L^{2} \text { CASE }_{t}+a_{32}(L) \text { BEN }_{t}+a_{33}\left(L^{2}\right) \text { UNEM }_{t}+E_{3 t}\right.
\end{aligned}
$$

where CASE is the AFDC caseload, BEN is the real AFDC benefit, UNEM is unemployment, and the E's are random disturbance terms. Tests of the joint significance of the âij(L) will indicate Granger-causal relationships within the system. For example, if benefits encourage the choice of unemployment in order to qualify for welfare $(B E N \rightarrow \mathrm{UNEM} \rightarrow \mathrm{CASE})$, then the $\hat{\mathrm{a}}_{32}(\mathrm{~L})$ and $\hat{\mathrm{a}}_{13}(\mathrm{~L})$ would differ significantly from zero.

The data are monthly observations of national averages from October 1974 to October 1987 for whites and from October 1974 to December 1982 for minorities. ${ }^{9}$ Complete series on monthly earnings are not available, hence the omission of earnings from the empirical model. We consider two measures of the caseload, the number of families on AFDC and the number of individual recipients. The family caseload will capture any influence of benefits on family participation and on the formation of female-headed households. The individual recipient caseload will capture any effect of benefits on individual participation and on family size.

We disaggregate the unemployment statistic, measured as either the rate or level, by race and gender. ${ }^{10}$ This will enable us to detect differences in responses to welfare and employment opportunities by race and gender. Previous research suggests that such differences are likely. For example, Bergman (1971) presents evidence that discrimination crowds blacks into certain occupations, resulting in the lower marginal productivity of blacks with the same education as whites. Barrett and Morgenstern (1974) conclude that if blacks were not so concentrated in service jobs and unskilled occupations their employment rate would be significantly higher.

Differences across genders will be particularly important because the majority of AFDC recipients live in female-headed households. Labor supply studies 
Table 1. Causality patterns for family caseload and unemployment of blacks and other minorities

\begin{tabular}{|c|c|c|c|c|c|}
\hline & \multicolumn{3}{|c|}{ Marginal significance of F-test } & \multicolumn{2}{|c|}{ Marginal significance of $Q(27)$} \\
\hline & Case & Ben & Unem & & \\
\hline Case & .000 & .020 & .700 & .219 & $\mathrm{BEN} \rightarrow \mathrm{CASE}$ \\
\hline Ben & .516 & .536 & .707 & .957 & \\
\hline $\begin{array}{l}\text { Unem } \\
\text { (level) }\end{array}$ & .803 & .599 & .094 & .952 & UNEM \\
\hline Case & .000 & .033 & .572 & .125 & $\mathrm{BEN} \rightarrow \mathrm{CASE}$ \\
\hline Ben & .487 & .419 & .675 & .891 & \\
\hline $\begin{array}{l}\text { Unem } \\
\text { (rate) }\end{array}$ & .861 & .747 & .244 & .879 & UNEM \\
\hline Case & .000 & .064 & .934 & .642 & $\mathrm{BEN} \rightarrow \mathrm{CASE}$ \\
\hline Ben & .475 & .606 & .905 & .950 & \\
\hline $\begin{array}{l}\text { Unem } \\
\quad \text { (male level) }\end{array}$ & .864 & .519 & .329 & .993 & UNEM \\
\hline Case & .000 & .086 & .919 & .578 & $\mathrm{BEN} \rightarrow \mathrm{CASE}$ \\
\hline Ben & .422 & .552 & .848 & .886 & \\
\hline $\begin{array}{l}\text { Unem } \\
\text { (male rate) }\end{array}$ & .887 & .274 & .470 & .974 & UNEM \\
\hline Case & .000 & .023 & .352 & .005 & $\mathrm{BEN} \rightarrow \mathrm{CASE}$ \\
\hline Ben & .452 & .627 & .646 & .971 & \\
\hline $\begin{array}{l}\text { Unem } \\
\text { (female level) }\end{array}$ & .928 & .850 & .027 & .675 & UNEM \\
\hline Case & .000 & .017 & .220 & .002 & $\mathrm{BEN} \rightarrow \mathrm{CASE}$ \\
\hline Ben & .495 & .682 & .738 & .987 & \\
\hline $\begin{array}{l}\text { Unem } \\
\text { (female rate) }\end{array}$ & .922 & .947 & .061 & .515 & UNEM \\
\hline
\end{tabular}

typically find that women's supply of labor is more elastic than men's (e.g., Hausman, 1981). This difference means that the effects of changes in wages or welfare on labor force participation and hours worked may differ across genders.

Women may respond differently because they often bear primary responsibility for the care of children. Burkhauser and Duncan (1989) find that women are six times more likely than men to slip into poverty following divorce. They are twice as likely as men to become poor following the birth of a child. Bowen and Finegan (1969) and Blau and Robins (1988) present evidence that the presence of young children is a significant and negative influence on women's labor supply. Furthermore, work by Connelly (1989) suggests that unmarried mothers are more sensitive to the price of child care than are married mothers. The additional costs and constraints single mothers face will likely influence their responses to welfare and employment opportunities. Lowering benefits 
Table 2. Causality patterns for recipient caseload and unemployment of blacks and other minorities

\begin{tabular}{|c|c|c|c|c|c|}
\hline & \multicolumn{3}{|c|}{ Marginal significance of $F$-test } & \multicolumn{2}{|c|}{ Marginal significance of Q (27) } \\
\hline & Case & Ben & Unem & & \\
\hline Case & .000 & .039 & .790 & .076 & $\mathrm{BEN} \rightarrow \mathrm{CASE}$ \\
\hline Ben & .490 & .638 & .711 & .913 & \\
\hline $\begin{array}{l}\text { Unem } \\
\text { (level) }\end{array}$ & .908 & .574 & .115 & .983 & UNEM \\
\hline Case & .000 & .048 & .717 & .043 & $\mathrm{BEN} \rightarrow \mathrm{CASE}$ \\
\hline Ben & .482 & .541 & .700 & .824 & \\
\hline $\begin{array}{l}\text { Unem } \\
\text { (rate) }\end{array}$ & .936 & .681 & .284 & .952 & UNEM \\
\hline Case & .000 & .103 & .917 & .253 & $\mathrm{BEN} \rightarrow \mathrm{CASE}$ \\
\hline Ben & .441 & .696 & .902 & .895 & \\
\hline $\begin{array}{l}\text { Unem } \\
\text { (male level) }\end{array}$ & .735 & .238 & .211 & .953 & UNEM \\
\hline Case & .000 & .110 & .878 & .323 & CASE \\
\hline Ben & .404 & .677 & .856 & .821 & $\searrow$ \\
\hline $\begin{array}{l}\text { Unem } \\
\text { (male rate) }\end{array}$ & .685 & .074 & .272 & .944 & UNEM \\
\hline Case & .000 & .006 & .166 & .002 & $\mathrm{BEN} \rightarrow \mathrm{CASE}$ \\
\hline Ben & .521 & .760 & .747 & .959 & \\
\hline $\begin{array}{l}\text { Unem } \\
\text { (female level) }\end{array}$ & .949 & .854 & .030 & .753 & UNEM \\
\hline Case & .000 & .004 & .095 & .000 & $\mathrm{BEN} \rightarrow \mathrm{CASE}$ \\
\hline Ben & .562 & .801 & .826 & .981 & $\nearrow$ \\
\hline $\begin{array}{l}\text { Unem } \\
\text { (female rate) }\end{array}$ & .903 & .910 & .055 & .653 & UNEM \\
\hline
\end{tabular}

may discourage welfare recipiency and encourage labor force participation of some individuals, but it is less likely to have a similar impact on women who must care for children or pay someone else to do so.

The autocorrelation and partial autocorrelation functions of each series sug. gest that a first-differenced system in thirteen lags (a little over a year) is adequate. ${ }^{11}$ The Q-statistics (which test for higher order serial correlation) confirm model adequacy. ${ }^{12}$ Table 1 presents the results using the family caseload and minority unemployment statistics. AFDC benefits Granger-cause the family caseload in all six specifications. The caseload does not Granger-cause benefits, and unemployment does not Granger-cause the caseload. These results support only the work disincentive hypothesis.

Estimation of the system using the individual caseload produces slightly different results (Table 2). Benefits unilaterally Granger-cause the caseload in five of the six specifications. Benefits also appear to Granger-cause the rate of 
Table 3. Causality patterns for family caseload and white unemployment

\begin{tabular}{|c|c|c|c|c|c|}
\hline & \multicolumn{3}{|c|}{ Marginal significance of F-test } & \multicolumn{2}{|c|}{ Marginal significance of $Q(33)$} \\
\hline & Case & Ben & Unem & & \\
\hline Case & .000 & .028 & .454 & .294 & $\mathrm{BEN} \rightarrow \mathrm{CASE}$ \\
\hline Ben & .141 & .169 & .890 & .423 & $\searrow$ \\
\hline $\begin{array}{l}\text { Unem } \\
\text { (level) }\end{array}$ & .605 & .089 & .270 & .675 & UNEM \\
\hline Case & .000 & .048 & .723 & .391 & $\mathrm{BEN} \leftrightarrow \mathrm{CASE}$ \\
\hline Ben & .054 & .120 & .580 & .469 & \\
\hline $\begin{array}{l}\text { Unem } \\
\text { (rate) }\end{array}$ & .648 & .133 & .335 & .934 & UNEM \\
\hline Case & .000 & .064 & .480 & .221 & $\mathrm{BEN} \leftrightarrow \mathrm{CASE}$ \\
\hline Ben & .103 & .293 & .904 & .704 & $\searrow$ \\
\hline $\begin{array}{l}\text { Unem } \\
\text { (male level) }\end{array}$ & .791 & .080 & .276 & .951 & UNEM \\
\hline Case & .000 & .042 & .350 & .279 & $\mathrm{BEN} \leftrightarrow \mathrm{CASE}$ \\
\hline Ben & .078 & .326 & .729 & .737 & \\
\hline $\begin{array}{l}\text { Unem } \\
\text { (male rate) }\end{array}$ & .897 & .161 & .235 & .982 & UNEM \\
\hline Case & .000 & .054 & .265 & .789 & BEN $\leftrightarrow$ CASE \\
\hline Ben & .081 & .091 & .956 & .612 & \\
\hline $\begin{array}{l}\text { Unem } \\
\text { (female level) }\end{array}$ & .929 & .290 & .239 & .613 & UNEM \\
\hline Case & .000 & .086 & .277 & .604 & $\mathrm{BEN} \leftrightarrow \mathrm{CASE}$ \\
\hline Ben & .056 & .072 & .852 & .412 & \\
\hline $\begin{array}{l}\text { Unem } \\
\text { (female rate) }\end{array}$ & .946 & .246 & .261 & .774 & UNEM \\
\hline
\end{tabular}

unemployment among minority men. Both of these results support the work disincentive hypothesis. The rate of minority female unemployment, however, Granger-causes the AFDC caseload. This result supports the macroeconomic model instead. Lastly, there is no evidence that the caseload Granger-causes the benefits.

Table 3 presents the results when we estimate the system using the family caseload and white unemployment statistics. Feedback between benefits and the caseload appears in five of the six specifications. This result supports both the work disincentive and the public choice models. Benefits also Grangercause the level of white unemployment and the level of unemployment among white males. These patterns also support the work disincentive hypothesis.

The causal patterns differ further when we measure the caseload as the number of individual AFDC recipients (Table 4). Only three specifications exhibit significant feedback between the caseload and real benefits. Benefits unilaterally Granger-cause the individual caseload in the remaining equations. Benefits 
Table 4. Causality patterns for recipient caseload and white unemployment

\begin{tabular}{|c|c|c|c|c|c|}
\hline & \multicolumn{3}{|c|}{ Marginal significance of F-test } & \multicolumn{2}{|c|}{ Marginal significance of $Q(33)$} \\
\hline & Case & Ben & Unem & & \\
\hline Case & .000 & .010 & .539 & .466 & $\mathrm{BEN} \rightarrow \mathrm{CASE}$ \\
\hline Ben & .149 & .214 & .887 & .332 & $\searrow$ \\
\hline $\begin{array}{l}\text { Unem } \\
\text { (level) }\end{array}$ & .741 & .052 & .361 & .617 & UNEM \\
\hline Case & .000 & .016 & .629 & .520 & $\mathrm{BEN} \leftrightarrow \mathrm{CASE}$ \\
\hline Ben & .062 & .186 & .600 & .388 & $\searrow$ \\
\hline $\begin{array}{l}\text { Unem } \\
\text { (rate) }\end{array}$ & .739 & .072 & .359 & .957 & UNEM \\
\hline Case & .000 & .022 & .628 & .293 & $\mathrm{BEN} \rightarrow \mathrm{CASE}$ \\
\hline Ben & .126 & .326 & .917 & .671 & 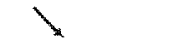 \\
\hline $\begin{array}{l}\text { Unem } \\
\text { (male level) }\end{array}$ & .927 & .087 & .399 & .911 & UNEM \\
\hline Case & .000 & .018 & .538 & .348 & $\mathrm{BEN} \leftrightarrow \mathrm{CASE}$ \\
\hline Ben & .086 & .374 & .733 & .650 & \\
\hline $\begin{array}{l}\text { Unem } \\
\text { (male rate) }\end{array}$ & .971 & .173 & .333 & .968 & UNEM \\
\hline Case & .000 & .020 & .328 & .756 & $\mathrm{BEN} \rightarrow \mathrm{CASE}$ \\
\hline Ben & .128 & .108 & .967 & .588 & \\
\hline $\begin{array}{l}\text { Unem } \\
\text { (female level) }\end{array}$ & .931 & .218 & .210 & .658 & UNEM \\
\hline Case & .000 & .026 & .188 & .561 & BEN $\leftrightarrow$ CASE \\
\hline Ben & .105 & .092 & .921 & .476 & \\
\hline $\begin{array}{l}\text { Unem } \\
\text { (female rate) }\end{array}$ & .967 & .195 & .218 & .855 & UNEM \\
\hline
\end{tabular}

also Granger-cause unemployment in half of the specifications. Specifically, benefits Granger-cause white unemployment (level and rate) and the level of white male unemployment.

In summary, the tests generally support the work disincentive model's hypothesis that benefits cause the caseload. This pattern appears consistently across race and gender. The tests produce weak evidence that benefits Grangercause unemployment. This pattern appears most frequently for whites and males. This suggests that the unemployment of women is determined by factors other than the level of welfare benefits.

Eight specifications (all using white labor statistics) indicate feedback between caseloads and benefits. These cases provide the only support for the public choice hypothesis that caseloads cause benefits. However, it is not clear why the caseload Granger-causes benefits only when we control for unemployment among whites.

The use of unemployment statistics to measure labor responses to welfare 
Table 5. Causality patterns among benefits, caseloads, and labor force participation rates: Whites Marginal significance of F-test Marginal significance of $Q$

\begin{tabular}{llllll}
\hline Families & & & & & \\
& Case & Ben & LFP & & \\
\cline { 2 - 5 } Case & .0000 & .0652 & .0228 & .1516 & BEN $\rightarrow$ CASE \\
Ben & .1420 & .0237 & .2899 & .9389 & $\nearrow$ \\
LFP & .0944 & .1300 & .0000 & .6691 & LFP \\
$\quad$ (rate for females) & & & & & \\
Case & .0000 & .0190 & .0012 & .9523 & BEN $\rightarrow$ CASE \\
Ben & .8468 & .2336 & .0621 & .8864 & $\nearrow$ \\
LFP & .4927 & .1558 & .0000 & .0170 & LFP \\
$\quad($ rate for males) & & & & & \\
Individuals & & & & & \\
Case & .0000 & .0012 & .0119 & .6479 & BEN $\rightarrow$ CASE \\
Ben & .0510 & .0331 & .1136 & .7813 & \\
LFP & .1817 & .3150 & .0000 & .8448 & LFP \\
$\quad$ (rate for females) & & & & & \\
Case & .0000 & .0039 & .0004 & .8148 & BEN $\rightarrow$ CASE \\
Ben & .8757 & .4283 & .1500 & .8764 & $\nearrow$ \\
LFP & .3138 & .1416 & .0000 & .0216 & LFP \\
$\quad$ (rate for males) & & & & & \\
\hline
\end{tabular}

benefits may be too restrictive: Generous benefits could induce withdrawal from the labor force. Tables 5 and 6 present the results when we estimate the system using labor force participation rates instead of unemployment statistics. ${ }^{13}$ Benefits unilaterally Granger-cause the caseload in seven of the eight specifications. These results are consistent with the work disincentive hypothesis.

Unemployment generally does not Granger-cause welfare caseloads, but labor force participation does: all eight specifications exhibit this pattern. Also, while earlier results offered limited evidence that benefits Granger-cause unemployment, there is no evidence that benefits Granger-cause labor force participation. In fact, labor force participation rates Granger-cause the benefits in three of the specifications. In short, benefits do not appear to affect labor force participation as the work disincentive model predicts. If the presence of small children more strongly influences the decision to withdraw from the labor force than do AFDC benefits we would expect exactly these results.

Male labor force participation rates also seem to matter. In all four specifications male labor force participation Granger-causes the AFDC caseload. This 
Table 6. Causality patterns among benefits, caseloads, and labor force participation: Blacks and other minorities

\begin{tabular}{|c|c|c|c|c|c|}
\hline \multirow{2}{*}{ Families } & \multicolumn{3}{|c|}{ Marginal significance of F-test } & \multicolumn{2}{|c|}{ Marginal significance of $Q(27)$} \\
\hline & & & & & \\
\hline & Case & Ben & LFP & & \\
\hline Case & .0000 & .0077 & .0203 & .2404 & $\mathrm{BEN} \rightarrow \mathrm{CASE}$ \\
\hline Ben & .2319 & .1763 & .2112 & .7921 & $\nearrow$ \\
\hline $\begin{array}{l}\text { LFP } \\
\quad \text { (rate for females) }\end{array}$ & .3959 & .5830 & .0000 & .2164 & LFP \\
\hline Case & .0000 & .0190 & .0363 & .8927 & $\mathrm{BEN} \rightarrow \mathrm{CASE}$ \\
\hline Ben &.$\$ 241$ & .2182 & .0331 & .4435 & $\checkmark$ \\
\hline $\begin{array}{l}\text { LFP } \\
\text { (rate for males) }\end{array}$ & .1981 & .5883 & .0000 & .4137 & LFP \\
\hline \multicolumn{6}{|l|}{ Individuals } \\
\hline Case & .0000 & .0013 & .0104 & .6551 & $\mathrm{BEN} \rightarrow \mathrm{CASE}$ \\
\hline Ben & .4557 & .2561 & .3602 & .8508 & $\varnothing$ \\
\hline $\begin{array}{l}\text { LFP } \\
\quad \text { (rate for females) }\end{array}$ & .1798 & .5322 & .0000 & .2410 & LFP \\
\hline Case & .0000 & .0009 & .0030 & .9506 & $\mathrm{BEN} \rightarrow \mathrm{CASE}$ \\
\hline Ben & .6521 & .2161 & .0395 & .4292 & $\checkmark \quad$ \\
\hline $\begin{array}{l}\text { LFP } \\
\quad \text { (rate for males) }\end{array}$ & .1040 & .6449 & .0000 & .1850 & LFP \\
\hline
\end{tabular}

suggests that low male labor force participation Granger-causes the caseload. But what causes low male labor force participation? Certainly high unemployment and/or low wages are possible factors.

\section{Summary and conclusions}

Table 7 summarizes our findings with respect to each of the three models of the welfare caseload. The Granger causality tests reveal that AFDC benefits generally Granger-cause the caseload. This finding supports the work disincentive hypothesis that benefits cause people to join the welfare rolls. However, benefits may cause higher caseloads by prompting a behavioral response or, if the benefits rise due to a decrease in the tax rate, by extending eligibility. The work disincentive model also predicts that benefits cause unemployment. This pattern appears in only six specifications, most of which use white unemployment measures. Lastly, there is no evidence that benefits Granger-cause labor force participation.

The public choice model garners some support. While there is no evidence 
Table 7. Summary of results

\begin{tabular}{lll}
\hline Model/Hypothesis & Implied causal patterns & Fraction of supporting tests* \\
\hline Work disincentive & BEN $\rightarrow$ CASE & $31 / 32$ \\
& BEN $\rightarrow$ UNEM & $6 / 24$ \\
& BEN $\rightarrow$ LFP & $0 / 8$ \\
Public Choice & CASE $\rightarrow$ BEN & $9 / 12$ \\
Macroeconomic & UNEM $\rightarrow$ CASE & $1 / 24$ \\
& LFP $\rightarrow$ CASE & $8 / 8$ \\
\hline
\end{tabular}

* Tests significant at $90 \%$ or higher levels. Includes tests which indicate feedback (mutual causation).

that the caseload unilaterally Granger-causes benefits, nine specifications exhibit feedback between the caseload and benefits. The tests offer virtually no support for the hypothesis that unemployment causes welfare caseloads. Labor force participation rates, on the other hand, do Granger-cause the caseload (but benefits do not Granger-cause labor force participation). This result is consistent with the hypothesis that the presence of young children is probably a more important determinant of women's labor supply than are welfare benefits. If true, lower benefits may not increase the labor force participation of female heads, nor will increases in job training programs, unless affordable child care becomes readily available.

These results must be taken as suggestive rather than as conclusive. As in all causality tests, the results can be misleading when the model omits important variables. Nevertheless, the use of the Granger-causality test reveals some intriguing patterns and offers some insight into the relationships between benefits, caseloads, unemployment, and labor force participation. This approach offers a relatively simple way to test the implications of a variety of competing models of the effects of benefits and labor market conditions on welfare caseloads.

\section{Notes}

1. For example, after touring Britain in 1776 Ben Franklin warned that the English welfare policy "offered a premium for the encouragement of idleness, and you should not now wonder that it has had its effect in the increase in poverty." On the Price of Corn and Management of the Poor.

2. For example, see Hausman (1981) and Moffitt (1983) for estimated responses based on data from the Panel Study of Income Dynamics. Ashenfelter presents estimates using SIME/DIME data.

3. The other major cause of the increase in AFDC participation over this period was the lowering of the implicit tax rate. This change made more citizens eligible for AFDC. 
4. For example, Cebula (1976) presents a regression analysis in which the number of persons on AFDC significantly and positively influences the benefit level.

5. Anderson (1987) also finds that AFDC payments are not significantly correlated with the poors' voting strength or lobbying efforts.

6. Inman (1978) tests the validity of the assumption that the median voter is the voter with the median income. He finds that the data are generally consistent with this assumption.

7. Increasing caseloads could cause benefits to fall. Many analyses of state budgeting find that the greater the number of poor, or the greater the ratio of poor to nonpoor, the lower is total state expenditure on welfare (e.g., Orr, 1976). Also, if the poor tend to congregate in public areas such as commuter stations and beg, the nonpoor may feel overwhelmed, irritated, and even resentful. Support for welfare could then decrease.

8. For a review of the causality literature see Pierce and Haugh (1977).

9. The monthly AFDC caseloads and nominal benefits were provided by Emmett Dye, Office of Family Assistance, Department of Health and Human Services. We use the CPI-U, published in the Survey of Current Business, to calculate real benefits. The unemployment statistics are all published in Employment and Earnings. Prior to January 1983 the BLS reported unemployment statistics for "whites" and "blacks and others". Beginning in January 1983 the categories changed to "whites", "blacks only", and "others".

Using national averages may induce some aggregation bias.

10. Complete records of the monthly caseload by race are not available over the sample period.

11. The Akaike, Schwarz, and Final Prediction Error (FPE) criteria were also calculated for the first system specification. All three confirmed the choice of thirteen lags.

12. $Q(p)$ is the Ljung-Box autocorrelation test statistic:

$$
Q=N(N+2)\left[\sum_{j=1}^{m} \frac{1}{N-j} r_{j}^{2}\right]
$$

where $r_{j}$ is the $j$ th lag autocorrelation of the residuals. This statistic tests the null hypothesis that the residuals are white noise, i.e., there is no serious high order autocorrelation. See Ljung and Box (1978).

13. Monthly labor force participation rates are reported only for whites and minorities disaggregated by gender.

\section{References}

Abraham, K. (1983). Structural/frictional vs. deficient demand unemployment: Some new evidence. American Economic Review 73 (4): 708-723.

Anderson, G. (1987). Welfare programs in the rent-seeking society. Southern Economic Journat 54 (2): $377-386$.

Ashenfelter, O. (1983). Determining participation in income-tested social programs. Journal of the American Statistical Association 78 (383): 517-525.

Barrett, N. and Morgenstern, R. (1974). Why do blacks and women have high unernployment rates? Journal of Human Resources 9 (4): 453-464.

Bassi, L. (1990). Employment and welfare participation among women. Economic Inquiry 28: 222-238.

Bergman, B. (1971). The effect on white incomes of discrimination: Employment. Journal of Political Economy 79 (1): 294-313.

Blau, D. and Robins, P. (1988). Child-care costs and family labor supply. Review of Economics and Statistics 70 (3): 374-381. 
Bowen, R. and Finegan, T. (1969). The economics of labor force participation. Princeton: Princeton University Press.

Burkhauser, R. and Duncan, G. (1989). Economic risks of gender roles: Income loss and life events over the life course. Social Science Quarterly 70: 3-23.

Cebula, R. (1976). A note on nonwhite migration, welfare levels, and the political process. Public Choice 28: 117-119.

Connelly, R. (1989). Determinants of weekly child care expenditures: A comparison of married and unmarried mothers. Bowdoin College Working Paper.

Danziger, S., Haveman, R. and Plotnick, R. (1981). How income transfer programs affect work, savings, and the income distribution: A critical review. Journal of Economic Literature 19: $975-1028$.

Granger, C.W.J. (1969). Investigating causal relations by econometric models and cross-spectral methods. Econometrica 34: 424 438.

Hausman, J. (1981). Labor supply. In H. Aaron and J. Pechman (Eds.), How taxes affect economic behavior, 27-83. Washington DC: Brookings Institution.

Inman, R. (1978). Testing political economy's "as if" proposition: Is the median income voter really decisive? Public Choice 33: 45-65.

Leffler, K. (1978). Minimum wages, welfare, and wealth transfers to the poor. Journal of Law and Economics 201 (2): 476-494.

Ljung, G.M. and Box, G.E.P. (1978). On a measure of lack of fit in time series models. Biometrika 67: $297-303$.

Moffitt, R. (1983). An economic model of welfare stigma. American Economic Review 73: $1023-1035$.

Murray, C. (1984). Losing ground: American social policy, 1950-1980. New York: Basic Books.

Orr, L. (1976). Income transfers as a public good: An application to AFDC. American Economic Review 66 (3): 359-371.

Pierce, D.A. and Haugh, L.D. (1977). Causality in temporal systems: Characterizations and a survey. Journal of Econometrics 5: 265-293.

Piven, F. and Cloward, R. (1971). Regulating the poor: The function of public welfare. New York: Pantheon Books.

Tullock, G. (1983). The economics of income distribution. Boston: Kluwer-Nijhoff.

Wilson, W.J. (1987). The truly disadvantaged. Chicago: University of Chicago Press. 